\title{
Functional Analysis of the Modern Civil Society through the Lens of Welfare State
}

\author{
Au T. I. ${ }^{1}$, Veselskaya N. R. ${ }^{1}$, Karzhasova G. B. ${ }^{1}$, Filin V. V. ${ }^{1}$, Baikenzhina K. A. ${ }^{1}$ \& Akhmetova K. S. ${ }^{1}$ \\ ${ }^{1}$ Karaganda Economic University of Kazpotrebsoyuz, Kazakhstan \\ Correspondence: Au T. I., Karaganda Economic University of Kazpotrebsoyuz, Kazakhstan.
}

Received: July 17, 2019

doi:10.5539/jpl.v12n3p53
Accepted: August 1, $2019 \quad$ Online Published: August 7, 2019

URL: https://doi.org/10.5539/jpl.v12n3p53

\begin{abstract}
The growing opportunities of the civil society institution and its specific influence on the processes occurring at the current stage of economic development highlights the current importance of this study. This necessitates an objective need to examine the concept and essence of welfare state (social state), as well as to analyze the civil society as an element influencing its formation, ensuring the prospects of development and formation of real rule-of-law democratic state. Thus, this article aims to study the current state of civil society institution and to justify the need for ensuring the high level of social security for its citizens, on the basis of social partnership and social responsibility of the state, business structures and civil society.

The main research methods that enabled to comprehensively examine the studied problem were the analysis of theoretical and regulatory legal acts, study of the foreign experience. The article presents the results of legal regulation analysis and problems related to the formation of civil society institution in Kazakhstan.
\end{abstract}

Keywords: civil society, welfare state, local authorities, free development, self-realization, personality, legislation improvement

\section{Introduction}

Civil society institutions play a vital role in the development of welfare statehood in the Republic of Kazakhstan during the transition to sustainable development, since civil society is a sum of citizens and various associations that operate within the framework of the state regulatory legal acts. However, their activities are carried out independently of the state and are aimed at protecting the rights and interests of citizens guided by universally recognized principles and values.

At the same time, the interests of the state are often opposed to those of civil society, which leads to contradictions and tensions within the country. Meanwhile, their mutual responsibility for the fate of the citizens of a sovereign state is overlooked and ignored. Since the strength of civil society depends entirely on the initiative and activity of the citizens themselves, there is a need to consider the relationship between civil society and the welfare state. In this regard, there is the utmost importance to define the concept and essence of the welfare state and to analyze the concept of civil society.

According to Parasiuk (2008), civil society is presented as a certain social space where people interact as individuals independently of each other and from the state. A person, who has the right for realization economic, cultural, spiritual and political potentials, acts as an important condition of the existing of the civil society. A person is able to act freely for the achievement of own goals, whereas the civil society is obliged, by means of legal mechanisms, to protect person's interests and protect from all the troubles. At the same time, the person is obliged to observe all the rights of civil society, to work for it and to harmonize all own actions with its interests and interests of other members.

Khokonov in his work (2009) emphasized that the civil society and rule-of-law state are complex paired political and law categories. The complexity of the theoretical understanding of these concepts lies in the linking of the concepts of "law", "state", "society". The complex nature of the relationship of these phenomena lies in the maxim: without civil society, there is no rule-of-law state, and without the rule-of-law state, it is impossible to become a full-fledged civil society. The rule-of-law state does not oppose civil society, furthermore, it creates conditions for its normal functioning and improvement, as it objectively integrates the interests and values of all social strata and groups of the population. In such integration, there is a guarantee of solution of the arising 
contradictions in a legal civilized way, a guarantee of exclusion of social cataclysms, a guarantee of nonviolent progressive development of society. Due to the fact that the social basis of the rule-of-law state is the civil society, in the structure of the concept of the rule-of-law state there are highlighted the principles of cooperation between the state and civil society in various fields: lawmaking, division of powers, the organization of control over compliance with the law.

Levashov (2014) notes that, as history demonstrates, an effective welfare state arises under the condition of interaction of members of society, freely organized in the historically formed social and national space, with the state policy aimed at harmonizing interests, creating material conditions, labor motivation and spiritual factors for the realization of needs. In each individual country, the welfare state comes through its historical path of development and takes its own special national forms.

If to observe it not within the framework of national specifics, welfare state should be considered as a social phenomenon that occurs in the process of formation of socially-oriented values and work motivation in the interests of the majority of society members and sustainable development of civilization on the planet.

Kutuzov (2015) emphasized that the idea of the state, which purpose of the formation and functioning is to ensure full social protection of the individual and society, the creation of decent living conditions for each person, regardless of their rate of participation in the production of certain material goods, has gained wide popularity in studies and is reflected in the constitutions of many countries.

The most important features of the welfare state, according to the author, include:

- great economic potential, contributing to the development of measures for the redistribution of income, without significantly affecting the position of individual owners;

- the state has such interrelated goals as the establishment of social justice in society, the establishment of the common good, equal initial opportunities for self-realization of an individual, etc.;

- the existence of civil society, for which the state serves as a tool and regulator of socially-oriented policies (Kutuzov, 2015).

Kochetkova in her study (2009) notes that the legally-obligatory character of the welfare state is its essential characteristic, the meaning of which is that the state, being social, not only performs some charitable activity in relation to its citizens, but does it with necessity, by virtue of the undertaken responsibility. It is the duty of the state to take care of the person, and not the care itself, that is the main, fundamental difference of the welfare state from any other.

Any state performs certain social functions, in one form or another showing concern for its citizens. A distinctive feature of the welfare state is that, starting from a certain point in its historical development, the state recognizes the performance of these functions as its duty, thereby giving the person the right not just to receive assistance from the state in the form of mercy, but to receive it, first, as a guaranteed thing; secondly, to be competent to demand from the state the fulfillment of social obligations assumed. This is the difference between the welfare state and paternalistic state, which simply cares about people and takes care of them. The author argues that the reason why the welfare state is not only obliged to perform its tasks, but also interested in their implementation, in the end, is that the development of the individual is a necessary condition not only for the development of society, but also for the preservation of the state itself. Where basic human needs are met and high social guarantees are achieved, i.e. where people are satisfied with their lives, there is no desire and aspiration to change something radically - this is how the necessary social and political stability and civil peace are achieved (Kochetkova, 2009).

\section{Materials and Methods}

As the main method of research was used the general dialectical cognition method, as well as the comparative legal analysis of the norms of Kazakhstan's legislation and critical analysis of the available scientific approaches to the studied issue. The foreign experience of certain countries on the formation of welfare state models was used, on which basis the ways to address the problem and improve the current legislation were proposed.

The aim of this article is to study the current state of civil society institution and to justify the need for ensuring the high level of social security for its citizens, on the basis of social partnership and social responsibility of the state, business structures and civil society.

\section{Results and Discussion}

As a legal category, the concept of "welfare state" first appeared in the Constitution (Basic Law) of Federative Republic of Germany (as a social state) in 1949. Then it became part of the Constitutions of France in 1958, 
Spain in 1978, Romania in 1991, Slovenia in 1991, Colombia in 1991, Peru in 1993, Ukraine in 1996, Ecuador in 1998, Venezuela in 1999, and a number of other countries, and, as was already noted, it is now presented in the Constitutions of Russian Federation (from 1993) and the Republic of Kazakhstan (from 1995).

However, the essence and content of this category in the legislation of Kazakhstan and Russia are not disclosed. Therefore, in most cases, the welfare state is interpreted as a state providing targeted social protection to certain groups of the population.

Thus, according to Mamut (2001), the welfare state is "a public-authoritative society organization, which is 'self-committed' to provide its members with certain social services (other than political, administrative, judicial services)". Baglay (2017) believes that the welfare state is "a state undertaking the obligations to take care of social justice, the welfare of its citizens, their social security". Also, a number of authors connect the understanding of the principle of the welfare state with the regulation of social relations.

Burdzhalov (1996) interprets the welfare state as "the main factor, regulator and creator of social processes in society, having a high degree of social responsibility that is achieved as a result of the implementation of a number of principles, forming the general concept and main avenues of social policy, its strategy, tactics, ensuring legislative and legal bases, implementing a wide range of social powers in relation to its citizens."

According to Pavlenok (2015), the welfare state is the defining type of the modern state, which assumes active intervention of the state in social and economic processes in order to regulate the social relations.

In our opinion, the above definitions reflect only one of the characteristics of a welfare state - the performance of a social function, which significantly impoverishes the content of the concept of "welfare state". Some definitions are formulated by specifying the basic principles implemented in the welfare state.

Other authors defining the concept of welfare state combine references to the social function of this state and implemented principles. For example, Goncharov (2000) defines a welfare state as "an institution that provides a high level of social security and protection of all citizens through intense activities on regulation of social, economic and other sectors of society, the establishment of social justice and solidarity."

Recently, the definition of the welfare (social) state has been revealed through the lens of the relationship "state-personality."

Thus, Lukyanenkov (2007) assumes: "Welfare state is a rule-of-law democratic state, which recognizes a person to be the highest value and takes responsibility for ensuring decent living standards, free development and self-realization of the creative (labor) potential of an individual. Social responsibility to society and citizens is an integral feature of such state."

The definition that is almost identical to the above is proposed in the Concept of the Formation of the Legal Framework and Mechanisms for the Implementation of the Welfare State in the Commonwealth Countries, adopted in St. Petersburg on May 31, 2007, and approved by the Inter-Parliamentary Assembly of the Commonwealth of Independent States no. 28-6: "Welfare state is a legal democratic state, which proclaims a human to be the highest value and creates conditions for ensuring decent living standards, free development and self-realization of creative (labor) potential of an individual. The decent living standards of a person is understood as material security at the level of the standards of modern developed society, access to the values of culture, the guarantee of the rights of personal security, and free development of a person is understood as his/her physical, mental and moral improvement" (Kubeev, 2012). Despite the identical nature of these definitions, there is a significant difference. Lukyanenkov mentioned an important factor of the welfare state - it takes responsibility for ensuring decent living standards, free development and self-realization of the creative (labor) potential of the individual, in contrast to the definition enshrined in the Concept, which indicates only that the welfare state creates conditions for ensuring this. A similar opinion is shared by many Kazakhstani authors, for example, Momysheva (2018).

In our view, the definition of a welfare (social) state should reflect the relationship between "state and society" and not only between "state and individual". Certainly, the welfare state pays due regard to the interests and rights of an individual in its policy, but the essence of such state should be considered differently, otherwise this state should be called anthropocentric. At the same time, the relations between the state and society predetermine the relations between the state and an individual.

We believe that the initial meaning of the term "social" should be preserved. Thus, in a broad sense, "social" means "generally related to the human community type of interaction and communication." The content of the category "social" is the joint nature of the various manifestations of human activity (Shmakov, Vavilina, \& Dunayev, 2007). 
It appears that the essence of the welfare (social) state is to harmonize the opposing interests between different groups, segments of society and within them, in order to create conditions for improving the well-being, the living standards of all members of society. This aspect was addressed in previous studies $(A u, 2016)$.

The welfare state itself can be interpreted as a state whose social function is to ensure a high level of social security for its citizens, on the basis of social partnership and social responsibility of the state, business structures and civil society.

In theory, scholars have already conducted the classification of welfare states. According to foreign researches Normann Furniss and Timothy Tilton (1977), Thomas Marshall (1981), Gøsta Esping-Andersen (1990), there are three main models of the welfare state. The first is the "the positive state" (example - USA), the second - "the social security state" (example - UK), the third - "the social welfare state" (example - Sweden).

1) "The positive state" is a state focused on ensuring the equal chances of well-being of all citizens, ensuring and guaranteeing of "equal opportunities", an example of such a state is the United States;

2) "The social security state," in addition to ensuring equal chances of citizens, creates conditions for full employment and guarantees to all citizens without exception to receive income not lower than the subsistence minimum, the United Kingdom is an example;

3) "The social welfare state" - provides full employment, equalizes differences in income of the entire population, creates numerous permanent state and public social services, for example - Sweden (Akhinov \& Kalashnikov, 2008).

Each model has its benefits and drawbacks. Thus, in the first model, the state provides more autonomy for the citizens themselves, however, it does not take into account the presence of socially passive citizens who, due to lack of skills, qualification, profession and specialty, cannot take care of themselves. The second model can to some extent generate social parasites, i.e. citizens who prefer to live on social benefits and not seeking employment. The third model may displease those segments of the population whose incomes, high taxes and fees ensure the well-being of socially vulnerable segments of the population.

In German political sociology, there are liberal, conservative and social-democratic welfare states which differ from each other on numerous parameters and features (Thiemeyer, 1990).

In this classification the liberal welfare state provides equal social chances to citizens (corresponds to "the positive state") and stems from the left-over principle of financing of needy, stimulating them to actively seek for job. The conservative welfare state comes from the need to ensure a balance of authorities' paternalistic measures with the targeted program of social support of groups and segments different by profession and income. It focuses on the priority of social security of the family, not the individual. Social-democratic state postulates equal social rights of citizens and provides them with equal social conditions and benefits. Within the framework of such a state, actual equality of social conditions is ensured. In fact, in the core of this classification is the principle of contrasting the market with social orientation of the state, the opposition of liberal and social ideas (Akhinov \& Kalashnikov, 2008).

In the case of a liberal welfare state, the implementation of social reforms was strongly influenced by the ideas of liberalism and led to the adoption of the postulate that everyone has rights on at least the minimum decent living conditions. In other words, in this type of state everything is subordinated to the market, and social functions are a forced concession dictated by the need to stimulate labor motivation and ensure the reproduction of the labor-power. The conservative model is a balance between the market and social goals when they are considered as two opposite poles in a dynamic equilibrium. In this case, social functions are no longer forced, as in the liberal model, but act as equivalent to the market. The conservative welfare state stems from the idea of partnership between the state, public and charitable organizations. It is this classification that formed the basis of many classifications given by other authors.

Miletsky (1998), after he conducted a comparative analysis of the specified above classifications, noticed similarities between the positive state and the liberal welfare state, social security state and the conservative welfare state, social welfare state and the social democratic state. He notes: "Therefore, the first category of countries in both theories include the United States and the United Kingdom, the second - Germany, France, Italy, the third - Sweden, Norway, Denmark, etc. With all the differences in these models, they have a single entity. This fact is respected by representatives of modern methodological approaches studying the phenomenon of the welfare state."

Moiseenko (2008) believes that: "In practice, there are three main models of welfare state - liberal, conservative and social democratic. The United States and other English-speaking countries are representatives of the liberal 
model, Sweden and other Scandinavian countries represent the social democratic model, Germany and other Western European countries - the conservative model. Thus only in Europe it is possible to distinguish three basic models of the welfare state: 1) "Scandinavian", or "Swedish", or (as Vogel (2000) calls it) "Nordic" model (Sweden, Norway, Finland, Denmark); 2) the "Catholic" or southern European model (including Orthodox Greece, along with Italy, Spain, Portugal and Ireland); and 3) Central European (Germany, France, Belgium, Austria, the Netherlands). At the same time, the fourth model of the modern welfare state can probably be "American" or liberal (USA, Canada, Australia and partly Japan). If to align all four main parameters (by Vogel) from the least pronounced social functions in the state to the most pronounced, then at the extreme poles we will have an "American" (with a minimum degree of social protection of the population) and a "Swedish" (with a maximum degree of protection) models. In this case, the "Catholic" (South European) model immediately follows the "American" (by European standards, the degree of social protection is minimal), and the "German" (Central European) model will precede the "Swedish" (the degree of social protection is approaching the Scandinavian level)."

The four-link classification is represented by Fedorov (2009): the Northern model (Denmark, Finland, Sweden, the Netherlands) feature a high level of social protection and the universal nature of the provision of benefits; the Anglo-Saxon model (United Kingdom, Ireland) has the universal nature of the provision of social benefits, but assistance is provided in extremely necessary situations; money is sent primarily to persons of working age; the Continental model (France, Germany, Belgium, Austria) has social protection on a professional and corporate basis. The amount of social benefits received depends on the size of employee's contributions; the Mediterranean model (Greece, Italy, Portugal, Spain) is a subtype of continental.

On the basis of parameters directory of Scandinavian labor movement, Miletsky (1998) introduces the following classification of types of foreign countries: Australia is liberal welfare state, Austria - conservative welfare state, Belgium - conservative welfare state, United Kingdom - liberal welfare state, Germany - conservative welfare state, Denmark - social democratic state, Ireland - conservative welfare state, Italy - conservative welfare state, Canada - liberal welfare state, the Netherlands - conservative welfare state, Norway - social democratic state, USA - liberal welfare state, Switzerland -liberal welfare state, Sweden - social democratic state, Finland conservative welfare state, France - conservative welfare state, Japan - liberal welfare state.

These classifications indicate the common features of welfare states. It can be noted that it is extremely difficult to develop a single classification, since there are many states, most of which form a welfare statehood, and they differ in the form of government, political regime and other characteristics. The presented classifications do not include the States of Asia and Latin America in their system, although up to the present time some of them have formed welfare states, the positive experience of which should be taken into account.

Therefore, some researchers suggest talking about the different level of sociality of a certain state: "In this approach, Sweden, pursuing its social policy through high taxes on citizens, as well as Kuwait, and the United Arab Emirates, social welfare which is provided in the absence of taxes, i.e. countries with different sources and nature of funding for their social programs, are welfare states with nearly the same set of social functions and can be considered as one type of welfare state, provided that only citizens of these countries are considered" (Akhinov \& Kalashnikov, 2008).

The relationships between civil society and the state are treated differently by researchers. Radina in her work (2007) states, that: "The first version represents civil society as a certain social wholeness, integrating to some extent into state structures, the second version - as a set of structures independent of the state."

Both of these positions are not as completely opposed as they may seem. The independence of civil society institutions from the state results in freedom of expression, there is possible an open disagreement with the decision of the government or other institutions of state power, the ability to resist strict regulations on the part of the state associated with their rights and freedoms. However, in order to perform the above, civil society must adhere to certain rules established by law (state), and the most effective at the moment is the activity through political parties, representatives of which are elected in the state authority bodies, local self-government bodies, i.e. in the bodies of public power.

Analysis of legal regulation and the stage of formation of civil society institutions in Kazakhstan shed light on several problems.

Firstly, there is a need to develop a definition of "civil society", as a correct understanding of the essence of civil society will enable establishing the right direction of development of civil society institutions.

Society becomes a civil one only at a certain stage of democratic development and is formed along with the 
economic and political development of the country, the growth of well-being, culture and self-consciousness of the people. The task of civil society is to mediate between an individual and the state. The purpose of civil society is to protect the interests of each member of society, represent their interests in the face of the government and society, public control over the activities of the government and the formation of domestic and foreign policy of this society. In our opinion, civil society should be understood as a society whose members, regardless of their affiliation to a public authority, through initiative within the law, can freely realize their interests and initiatives in priority areas of public life, as a rule, through self-organizing structures.

Secondly, currently, the legislator pays insufficient attention to labor collectives as a unit of civil society. Unfortunately, they are also undeservedly "forgotten" by theorists and even reduced to the level of structures that do not have legal personality.

For example, Nurtdinova (1998) believes that “...employers and representative organizations of employees should be recognized as parties to the collective bargaining process. It is impossible to agree with the provisions of the current legislation indicating employees as a social partner. The labor collective does not possess signs of a legal subject and cannot enter into legal relations."

We consider this statement to be entirely wrong. Due to some specific features of the development of civil society in Kazakhstan, the labor collective should be considered as an independent unit, which has the right to participate in solving issues of state and social life, due to the following reasons:

1) The system of trade unions in the Republic of Kazakhstan does not provide full coverage of all employees, and therefore their labor and social protection is not provided. There are no trade unions for journalists and small business representatives. Thus, in Kazakhstan, there are 26 branch trade unions at the national level and 14 regional trade unions. Nearly 2.1 million people are members of the Federation of Trade Unions. Among this number, 1.1 million work in education and medicine, 5 thousand are students and pensioners. Other members of trade unions are employees of the real sector of the economy. According to official statistics, the number of employees in Kazakhstan is 5.8 million people, and only a third of this number is part of trade unions (IP KZinform, 2012).

2) The existing trade unions, with the exception of trade unions of large enterprises, are passive and do not fulfil the role assigned to them - the protection of the rights and interests of employees. In Kazakhstan, vast majority of the population associates the activities of domestic trade unions with purely distributional functions: the distribution of material assistance, subsidized sanatoria and holiday-homes passes and new year's gifts. This is at the primary levels, and in the trade union bodies of the middle and higher levels, there are still stereotypes of thinking, a weak influence on current events, the lack of organized support from the primary levels, the aging of managerial personnel without training a quality reserve. As a result, the role of trade unions in the modern history of Kazakhstan, as well as their authority in society are extremely low (Kazprofnet, n.d.);

3 ) representation of the interests of the population is not fully represented by political parties. Thus, according to the legislation of the Republic of Kazakhstan, employees of law enforcement agencies and armed forces cannot be members of political parties, therefore, their ability to protect their social and other rights is limited;

4) in Kazakhstan, there is a formation of "self-consciousness" of labor collectives as a real force with financial and other opportunities for lobbying for their social, political and other interests.

As Maslennikov (1984), said: "The labor collective is the basic unit of socialist society... From the first years of Soviet power, the labor collective has played an important role in the formation of councils, and then in monitoring the activities of their executive bodies and deputies, and participated in the production management, in the activities of public control organs, in the protection of public order and through their representatives participated in the administration of justice."

Suvorova (n.d.) draws attention to the social significance of the labor collective: "The labor collective is a union of individuals that has a certain social structure, the status of the subject of labor law and has socially significant goals. It is important to note that the recognition of collective's status of the subject of labor law means the ability to perform legally significant actions on own behalf and in own interests, i.e. to be the bearer of subjective rights and obligations."

Gusov and Tolkunova (2003) noted: "In the labor collective, cooperative work ensures the unity and balance of interests of the society, the employer and the employee. Labor collectives are intended to increase material and spiritual wealth of the country, to rationally use the available resources, to display constant concern for the members of the collective about improving their working, material and recreation conditions."

According to Suvorova, the labor collective combines common features of the collective, including: 
a) a group of people united by certain activities;

b) a group of people with common interests and goals;

c) association of people with a certain organization and discipline.

As well as following specific features:

a) voluntary sustainable association of employees for joint work with common interests and objectives in a given labor organization;

b) associations of employees on the basis of their employment contracts by the same employer or on the basis of membership in the same production cooperative;

c) associations of employees, organized with the established discipline of work and unity of command in the course of work, with mutual responsibility of employees and the employer for labor offenses;

d) associations of employees from one production having organizational unity, governing bodies, independence in economic and other operations (Suvorova, n.d.)

The labor collective is quite capable to realize the social activity in three forms:

a) participation in the implementation and protection of their social rights as a subject of employment;

b) direct participation in the decision-making related to questions of public and state life;

c) participation in the decision-making related to questions of public and state life by means of representation (election their own representatives in public authorities).

In our opinion, there should be established legislative and regulatory framework in the Republic of Kazakhstan in order to labor collectives could have these opportunities.

Certainly, the position of increasing labor collectives' independence and their involvement in social life as an independent and equal partner may give rise to objections from opponents and, as an argument, there can be given the negative experience of self-government of Yugoslavia. However, the collapse of the self-government system of Yugoslavia occurred due to a number of reasons, one of which was the denationalization of the economic system, i.e. the removal of the state control over the economy and the restructuring of the economic organization on the basis of self-government.

The author's position involves raising the status of the labor collective as an equal partner of the state, business structures in the implementation of social policy in the Republic of Kazakhstan, but not monopolization of all spheres of activity, including economic.

Thirdly, the current legislation limits the possibility of developing civil society institutions for some categories of citizens. Thus, the Constitution of the Republic of Kazakhstan has restrictions for such categories of citizens of the Republic of Kazakhstan, as military personnel, employees of national security bodies, law enforcement agencies and judges referred to their union in order to protect their interests. According to the Federation of Trade Unions of Kazakhstan, there are restrictions on rights for judges to organize and join trade unions. This was explained by the fact that judges have a special legal status within the state system, which determines the constitutional restriction of their rights. However, according to the ILO Committee of Experts, the exceptions provided in Convention no. 87 "Freedom of Association and Protection of the Right to Organize" can only be applied to employees of police and armed forces. It is necessary to note that employees of the Ministry's central administration and departments for various reasons are not able to join trade unions in order to protect their rights, including in case of the reorganization of the state body (merger, accession, division, separation, reconstruction) (Suvorova, n.d.).

Fourthly, there are processes of governmentalization of some civil society institutions. In particular, the so-called National Chamber of Entrepreneurs, whose activities are regulated by the Law "On the National Chamber of Entrepreneurs of the Republic of Kazakhstan" dated from July 4, 2013, is an incomprehensible public association. Thus, in accordance with paragraph 1 of part 1 of article 5 of the Law of the Republic of Kazakhstan, the limits of mandatory membership fees are determined not by the Chamber itself, but by the Government of Kazakhstan. The thorough analysis of this law shows that this structure is a hybrid of a public association and a state body.

The identified problems require further rigorous research and development of ways to address these problems.

\section{Conclusion}

This article presents the results of legal regulation analysis and problems related to the formation of civil society 
institutions in Kazakhstan.

The analysis of the scholars' and experts' opinion made it possible to reveal the ration of institutions of welfare state and civil society, to identify the key areas of further ensuring the decent living standards, free development and self-realization of individual's creative potential. Emphasis is placed on the improvement of status of work community as an equal partner in implementation of state's social policy.

Analysis of legal regulation and the stage of formation of civil society institutions in Kazakhstan revealed certain problems. First, there is a need to develop a definition of "civil society", as a correct understanding of the essence of civil society will enable establishing the right direction of development of civil society institutions. Second, insufficient attention is currently paid by the legislator to labor collectives as a unit of civil society. Third, the possibility of developing civil society institutions for some categories of citizens (military personnel, employees of national security bodies, law enforcement agencies and judges referred to their union in order to protect their interests) are currently limited by the legislation. Fourth, there are processes of governmentalization of some civil society institutions.

The study's findings are of practical value for the employees of state and local authorities, civil organizations, as well as for researchers engaged in studying the problems of welfare state development and civil society formation.

\section{References}

Akhinov, G. A., \& Kalashnikov, S. V. (2008). Social policy. Theory and Practice. Moscow: ZAO "Ekonomika".

$\mathrm{Au}, \mathrm{T}$. I. (2016). Theoretical approaches to understanding of a welfare state in modern times. The Social Sciences (Pakistan), 16, 3956-3961.

Baglay, M. V. (2017). Constitutional right of the Russian Federation (12th ed.). Moscow: INFRA-M. Retrieved from http://znanium.com/catalog/product/901546

Burdzhalov, F. E. (1996). Modern social policy: between the plan and market. Moscow: Gardarika.

Decision of the Inter-Parliamentary Assembly of the Commonwealth of Independent States no. 28-6 "Concept of the Formation of the Legal framework and Mechanisms for the Implementation of the Welfare State in the Commonwealth Countries" (adopted in St. Petersburg on May 31, 2007). Received from http://docs.cntd.ru/document/902071503

Esping-Andersen, G. (1990). The three worlds of welfare capitalism. Cambridge: Polity Press.

Fedorov, S. M. (2009). Social policy in the European Union: from neoliberalism to the ideas of an active welfare state. In A. S. Avtonomov, \& I. N. Gavrilova (Eds.), Social policy within the framework of inter-sectoral interaction (pp. 384-392). Moscow: IS RAN.

Furniss, N., \& Tilton, T. (1977). The case for the welfare state. London: Indiana University Press.

Goncharov, P. K. (2000). Welfare state: essence and principles. Vestnik Rossiyskogo Universiteta Druzhby Narodov, series "Politology", 2, 46-59.

Gusov, K. N., \& Tolkunova, V. N. (2003). Labor law of Russia. Moscow: Prospekt.

IP Kzinform. (2012). The day of trade union official is celebrated in Kazakhstan. Received from https://kzinform.com/ru/

Kazprofnet. (n. d.). Five components of social modernization of mining and metals sector industry of Kazakhstan. Received from http://kazprofmet.kz

Khokonov, A. A. (2009). Rule-of-law state and civil society: Some aspects of interaction. Armiya i Obshchestvo, 3, 87-90.

Kochetkova, L. N. (2009). Philosophical discourse on welfare state. Tsennosti i Smysly, 3, 6-15.

Kubeev, E. K. (2012). Formation and development of welfare statehood under conditions of ongoing constitutional reforms in the Republic of Kazakhstan. Vestnik KarGU. Received from http://articlekz.com/node/1740?page $=2$

Kutuzov, A. A. (2015). Social function and welfare state. Common ground and differences. Mezhdunarodny Nauchno-Issledovatelskiy Zhurnal, 12(31), 57-58.

Levashov, V. K. (2014). Welfare state: historical genesis and the dynamics of its formation in Russia. Sotsiologicheskiye Issledovaniya, 7, 32-46. 
Lukyanenkov, M. V. (2007). Social responsibility of the state, business and citizens within the framework of tax relations (Doctoral dissertation). Penza.

Mamut, L. S. (2001). Welfare state from legal perspective. Gosudarstvo i Pravo, 7, 5-14.

Marshall, T. H. (1981). Values problems of welfare capitalism. In T. H. Marshall (Ed.), The right to welfare and other essays (pp.104-122). London: Heinemann Educational Books.

Maslennikov, V. A. (1984). Labor collective and its constitutional status. Moscow: Nauka.

Miletsky, V. P. (1998). Welfare state: evolution of theory and practice (political and sociological analysis) (Doctoral dissertation). St. Petersburg.

Moiseenko, T. V. (2008). The main tendencies of establishing and perspectives for formation of welfare state in modern Russia (Doctoral dissertation). Moscow.

Momysheva, F. S. (2018). Theoretical and practical aspects of welfare state. Konstitutsionnoye i Munitsipalnoye Pravo, 6, 12-15.

Nurtdinova, A. F. (1998). Collective agreement-based regulation of labor relationship: theoretical problems (Doctoral dissertation). Moscow.

Parasiuk, E. A. (2008). Civil society: general principles and conditions for its functioning. Vestnik $A G U$, series 1, 8, 296-300.

Pavlenok, P. D. (2015). Theory, history and methods of social work (10th ed.). Moscow: ITK "Dashkov i K". Retrieved from https://rucont.ru/efd/286887

Radina, N. K. (2007). Technologies of inter-cultural interaction in Russian civil society (Doctoral dissertation). Nizhny Novgorod.

Shmakov, V. S., Vavilina, N. D., \& Dunayev, V. Yu. (2007). Social policy: models and strategies. Novosibirsk: Parallel.

Suvorova, S. (n. d.). Labor collective: general characteristics and legal status. Received from http://www.new-fact.ru/?p=610

Thiemeyer, T. (1990). Theoretische Grundlagen der Sozialpolitik. Berlin: Duncker u. Humblot.

Vogel, J. (2000). The European welfare mix: redistribution of the social product in Sweden and the European Union: evolution and perspectives. Politeconom, 2(13), 53-80.

\section{Copyrights}

Copyright for this article is retained by the author(s), with first publication rights granted to the journal.

This is an open-access article distributed under the terms and conditions of the Creative Commons Attribution license (http://creativecommons.org/licenses/by/4.0/). 